\title{
The Effectiveness of Material Based Stories in Improving Students Reading Comprehension
}

\author{
Hasan Hasan; Ismail Ismail ${ }^{2}$ \\ ${ }^{1}$ Universitas Muhammadiyah Enrekang-Indonesia \\ Email: achank.hasan80@gmail.com ${ }^{1}$; smileummaspul@gmail.com²
}

\section{ARTICLE INFO}

Article History:

Received 20 June 2019

Accepted 08 Feburari 2020

Keywords:

Reading comprehension,

Material based stories

\begin{abstract}
This research was intended to explain the students reading comprehension through material based stories at the eighth grade of SMP Negeri 1 Maiwa Kabupaten Enrekang in the 2018/2019 academic year. This research used a quasi-experimental method class. It had conducted into two groups namely the experimental group and control group. The Sample in this research were 44 students. The researcher took real data from class to know the students reading comprehension. The instrument of this research was pre-test-posttest with multiple choice, $\mathrm{T} / \mathrm{F}$ and read test. From these findings, there was a significant effect on the students reading comprehension through material based stories. The data was analyzed by using a t-test and the result showed that the t-test value 4.629 was higher than the t-table value 2.021 . It meant that there was a significant difference between students' reading achievement before and after the treatment through the stories. It concluded that material based stories can be used in improving the reading comprehension of the students.
\end{abstract}

\section{INTRODUCTION}

Reading comprehension is a technique for improving students' success in extracting useful knowledge from text. As defined by the partnership for reading, reading comprehension is understanding a text that is read or the process of constructing meaning from a text.
Comprehension is a construction process because it involves all of the elements of the reading process working together as a text is read to concrete a presentation of the text in the reader's mind.

Skilled readers tend to be performing word recognition activities quickly and conveniently to help them understand text (Ismail, 2019). In both English and the first 
language learning contexts this definition is now widely accepted. (e.g., Adams, 1994; Just and Carpenter, 1987; Rayner and Pollatsek, 1989; LaBerge and Samuels, 1974; Samuels, 1994; Perfetti, 1985; Stanovich, 1991, 1992), and English as the second language learning contexts (e.g., Anderson, 1999; Day and Bamford, 1998; Eskey, 1988; Grabe, 1991). Nonetheless, it is possibly not the only reason for good understanding to be involved in recognition of terms (Ismail, Samad, \& Masnur, 2019). Background knowledge and skills in interpretation, such as prediction generation and inferences also affect the output of readers ' understanding (e.g., Anderson and Pearson, 1984; Carrell and Eisterhold, 1983). Nonetheless, creating automaticity in word recognition is important for first language or second language readers because "the fact that words are inadequate is highly unlikely to provide an excellent understanding" (Stanovich, 1992: 4). Effective readers must be in a position to decipher words in a text by means of "a kind of self-identification without deliberate cognitive effort." (Eskey, 1988: 94). These comments are particularly relevant to the second language reading teachers: reading in a foreign or second language is usually a slow, laborious process (Anderson, 1999; Jensen, 1986; Segalowitz, Poulsen, and Komoda, 1991).

\section{METHOD}

In this research, the researcher would apply the queasy experimental design. Students would be divided into two parts namely the experimental group and control group. (L.R.Gay:2006). Both classes were giving pre-test and post-test to measure students' reading comprehension. The experimental group would be given treatment by using stories text whether the control group only uses the conventional methods as the comparing with the experimenting, by this consideration, the researcher would saw the difference of achievement between experiment and control group. The researcher would use the cluster sampling technique which takes the two classes are VIII 1 and VIII, 3 students, as a sample. The total sample of this research describes as follow as 22 students as experimental group and 22 students as a control group.

The researcher would use the test as a method for data collection, they are pretest and post-test. The test is having the students' stories text according to the themes they are giving. The pretest aims at finding out the prior reading comprehension of the students, while the post-test aims at finding out the students' reading comprehension after treatment are giving stories. This test was used to measure students' reading comprehension. Data analysis method using a Windows test version inferential analysis in the SPSS 21.0 software.

\section{FINDINGS AND DISCUSSION}

This section deals with the presentation of students 'achievement in reading scoring classification of the students' pre-test and post-test.

\section{Scoring of student pre-test classification}

The researcher evaluated the students ' scores as the Experimental Group and the students as the Control Group after a study. Table 4.1 revealed the average for the scoring group. 
Table. 4.1. Experimental and control group classification of students' score

\begin{tabular}{lrrrrr}
\hline Classification & Score & \multicolumn{2}{r}{ Experimental Group } & \multicolumn{2}{r}{ Control Group } \\
& & $F$ & $\%$ & F & $\%$ \\
\hline Very Good & $86-100$ & - & - & - & - \\
\hline Good & $71-85$ & 7 & 31,81 & 2 & 9,10 \\
\hline Average & $56-70$ & 12 & 54,45 & 10 & 45,45 \\
\hline Poor & $41-55$ & 3 & 13,63 & 10 & 45,45 \\
\hline Very Poor & $0-44$ & - & - & - & - \\
\hline Total & & $\mathbf{2 2}$ & $\mathbf{1 0 0}$ & $\mathbf{2 2}$ & $\mathbf{1 0 0}$ \\
\hline
\end{tabular}

It is known from Table 4.1 that the students scored in the Experimental group, most of them were in the average category, the classification of 0 ( 0 per cent), 7 (31.81 per cent) were good, 12 (54.45) students on average, 3 (13.63 per cent) were bad and $0 \%$ (0 percent) were poor.

The Control Group score was primarily classified in the pre-test group as average and bad classification. 0 students $(0.0 \%)$ were very good, 2 (9.10\%) were good and 10 students (45.45\%) were on average, while 10 (45.45\%) were poor and $0(0 \%)$ were very bad.

\section{The mean and standard deviation of students' pre-test}

The average score and baseline of the students ' reading accomplishments can be found in the following table to assess whether the study group and control group were at or not at the same stage before treatment was conducted.
Table 4.2 Mean Score and Standard Deviation for the Experimental and Control Group Students ' Tests

\begin{tabular}{lll}
\hline Class & $\begin{array}{l}\text { Mean } \\
\text { Score }\end{array}$ & $\begin{array}{l}\text { Standard } \\
\text { Deviation }\end{array}$ \\
\hline $\begin{array}{l}\text { Experimental } \\
\text { Group }\end{array}$ & 68,18 & 8,802 \\
\hline Control Group & 58,86 & 7,704 \\
\hline
\end{tabular}

The mean score of the pre-test group and the control group was listed as an average in Table 4.2, and therefore the researchers concluded that the average score of the test groups of students was different from that of the control group. Table 4.2 indicates that This means that the readings between the experimental group and the control group before treatment were important between the students.

3. Scoring of student post-test classification At the conference, the researchers gave the students a post-test after interventions were applied to see if there was an increase in the performance of the students. The 
Table 4.3 The Classification of Students' Score for Experimental Group and Control Group on Post-test

\begin{tabular}{lcrrrrr}
\hline Classification & Score & \multicolumn{2}{c}{ Experimental Group } & \multicolumn{2}{r}{ Control Group } \\
\cline { 2 - 6 } & & $\mathrm{F}$ & $\%$ & $\mathrm{~F}$ & $\%$ \\
\hline Very good & $86-100$ & 1 & 4,54 & - & - \\
\hline Good & $71-85$ & 11 & 50,00 & 3 & 13,63 \\
\hline Average & $56-70$ & 10 & 45,45 & 10 & 45,45 \\
\hline Poor & $41-55$ & - & - & 9 & 40,92 \\
\hline Very Poor & $0-44$ & - & - & - & - \\
\hline & Total & $\mathbf{2 2}$ & $\mathbf{1 0 0}$ & $\mathbf{2 2}$ & $\mathbf{1 0 0}$ \\
\hline
\end{tabular}

Most of the students in the experimental group were in the good category from the table above. 1 (4.54\%) were very good students, 11 (50.00\%) were good students, 10 (45.45\%) were combined and the students were not bad or poor. They are not good students. 1 (4.54\%) This means that the score of the students has been improved from an average level to nice. This shows that after they taught by using stories, the students reading performance was increased.

While, there is a gap in the control group between the high and the low levels. Three $(13,63 \%)$ students were in a good grade, $10(45,45 \%)$ students were on average, and $9(40,92 \%)$ were in a low grade. None of the students were in very good and very bad grades.

\section{The mean score and standard deviation in post-test students}

The mean score and standard deviation are presented in table 4.4 to find out the difference between the post-test score of the experimental group and the control group.

Table 4.4 The Mean Score and Standard Deviation of Students' Post-test for Experimental Group and Control Group

\begin{tabular}{lll}
\hline Class & $\begin{array}{l}\text { Mean } \\
\text { Score }\end{array}$ & $\begin{array}{l}\text { Standard } \\
\text { Deviation }\end{array}$ \\
\hline Experimental Group & 72,50 & 8,556 \\
\hline Control Group & 61,14 & 7,704
\end{tabular}

The table 4.4. shows that the mean score between the two group varies from the treatment. The mean scoring was improved from 68.18 to 72.50 for the experimental group after the test. The mean poar-test score was graded into a good level, from mediocre to good level.

The mean post test score was increased from 58,86 to 61,14 in the control group on the other side. All mean scores were divided into an average level. Although the score was increased, it did not 
differ significantly. It has shown that reading achievement by using stories is better than did not use stories.

\section{Test of Significance (t-test)}

Inferential analysis was used to test the hypothesis mentioned earlier. In this case, a different t-test was used for the evaluation of Windows using the SPSS 21.0 software. The goal is to learn whether or not, at the level of a meaningful $\alpha=0,05$ or nonunrelated study, the discrepancy between the results of the student medium score in the experimental and control group is statistically significant $(\mathrm{N} 1+\mathrm{N} 2-2)=42$. The measurement result is described as follows:

Table 4.5 The T-test value on experimental group and control group of the students' reading achievement

\begin{tabular}{ccc}
\hline Variables & T-test Value & T-Test table \\
\hline Pre-test & 3.736 & 2.021 \\
Post-test & 4.629 & 2.021 \\
\hline
\end{tabular}

The researchers used t-test inferential statistics by means of SPPSS 21.0 in the Windows evaluation system to test the hypothesis, based on the results obtained by students and reported in the findings, to determine a higher value of the t-test than t-T $(3.736>2.021)$. it means that Ho was rejected and $\mathrm{H} 1$ was accepted. While in relation to the finding of the post-test, the t-test values are higher than the t-table $(4.629>2.021)$. this means that Ho was rejected and $\mathrm{H} 1$ was accepted, on a significant level of $\alpha=0.05$. it means that the use stories students reading achievement in the second years at SMP Negeri 1 Maiwa Kabupaten Enrekang

\section{DISCUSSION}

The students ' reading performance was improved by using stories, particularly for the experimental group, in a summary of the data collected during the test as described in the preceding section. The mean post-test score was reflected by the above value ( 68.18 to 72.50 ) than the mean pre-test score for the experimental group. The experimental group's post-test scoring showed also that students had reading progress.

In comparison, the reading ability of students in the experimental group and control group after treatment is significantly different, according to the previous section of data, where the students who used stories had higher results than those in the control group who did not use stories to comprehend them. It was confirmed by a difference from a control group (61.14) between the mean post test score in the experimental group (72.50).

The study has shown that the use of story increases the readability of studentsAlthough it is possible for both of them to enhance their reading output using traditional stories (without storytelling), using stories in the comprehension process have had a better impact than using conventional methods. This finding should be consistent with the capacity of good readers to decipher words in a text through "an automated recognition that involves no conscience of cognition" (Eskey, 1988: 94). The commentary on this is of particular importance to teachers in the second language: it is usually a slow and laborious process to translate international and 
second language (Anderson, 1999; Jensen, 1986; Segalovitz, Poulsen, and Komoda, 1991).

Based on the statistic test in asymptotic significant (2-tailed) column, in the pre-test of experimental group and control group, the researcher found that the probability values were higher than alpha $(\alpha) \quad(0.000>0.05)$ which means that there was no significant difference between the experimental group and the control group in pre-test. For both categories, the following findings are descriptive. The chance value was shown to be greater than alpha $(\alpha)(0.000>0.005)$. it means that $\mathrm{H} 1$ was accepted and Ho was rejected. It is concluded that there was a significant difference between the student reading achievement who used stories and who did not teach stories (conventional technique). In other words, after using stories from SMP Negeri 1 Maiwa Kabupaten Enrekang, the reading achievement was increased.

\section{CONCLUSION}

In relation to the research findings and discussion in the previous chapter, the conclusions are presented in the following statements, the data shows that the students' reading achievement before and after treatments are significantly differenced. It was found in post-test of experimental group where the mean score was 72.50 and standard deviation 8.556 was higher than the pre-test the mean score was 61.14 and the standard deviation was 7.704, which proved that the use stories in teaching reading comprehension contributed to the students' more productive in reading comprehension English. While in the control group, the mean score and standard deviation were rise too but not significantly from 58.86 to
61.14. In the meantime, the T-test of student reading output in pre-test values was greater than T-table $(3.736>2.021)$ for the experimental group and the control group and also higher (4.629>2,021 for post-test). This led to the conclusion that the user stories in reading have brought up an up to date way in English language reading comprehension of teaching.

\section{References:}

1) Abbott, Gerry, Greenwood, John, Mckeating Douglas: Wingar Peter 1981, The Teaching of English as an International Language: A Practice Guide Great Britain Biddels Ltd.

2) Chen, S.W. 2005. The Effect of Incorporated Reading Strategy Instruction for ESL Senior High School Students in Taiwan. Taiwan.

3) De Corte, E., Verschaffel, L., \& Van De Ven, A. (2001). Improving text comprehension strategies in upper primary school children: A design experiment. British Journal of Educational Psychology, 71, 531-550.

4) Depdikbud. 2006. Petunjuk Proses Pelaksanaan Belajar Mengajar dan Petunjuk Sistem Pendidikan. Jakarta: Depdikbud.

5) Dewitz, P. \& Dewitz, P.K. (2003). They can read the words, but they can't understand: Refining comprehension assessment: Comprehension problems can be difficult to detect and treat. The Reading Teacher, 56, 422-435.

6) Elihami, E., \& Syarif, I. (2017, November). Leadership Management And Education Planning: Developing The Entrepreneurship Training Of Islamic Education. In International Conference On Education (Vol. 1, No. 01). 
7) Elihami, E., \& Saharuddin, A. (2017). Peran Teknologi Pembelajaran Islam Dalam Organisasi Belajar. EdumaspulJurnal Pendidikan, 1(1), 1-8.

8) Ismail, I., Elihami, E., \& Mustakim, M. (2019). Students' Perceptions of the Benefits of Mobile Polling Technology in Teaching and Learning in College: Implications of Students' Participation and Academic Performance. Jurnal Pendidikan Progresif, 9(1), 89-104.

9) Ismail, I. (2019). Converting a Story from Students' Own Language in English to Increase Speaking Ability. Majesty Journal, 1(1), 5-18. https://doi.org/10.33487/majesty.v1i1.5 4

10) Ismail, I., Samad, I. S., \& Masnur. (2019). The Impact of Interactive Reading Using Local Folktales Stories in Supporting Students ' Vocabulary Achievement in Indonesian EFL. Majesty Journal, 1(2), 25-37.

11) Fisk, C. \& Hurst, B. (2003). Paraphrasing for Comprehension. The Reading Teacher. 57 (2), pp. 182-185.

12) Gay et al. 2006. Education Research: Competencies for Analysis and Applications. New Jersey: Merrill Prentice Hall.

13) Grellet, Francoise. 1988. Developing Reading Skills. London: Cambridge University Press.

14) Lee, S.W., \& Von Colln, T. (2003). The effect of instruction in the paraphrasing strategy on reading fluency and comprehension. Retrieved from Educational Resources Information Center.

15) Parker, R., Hasbrouck, J.E., \& Denton, C. (2002). How to tutor students with reading comprehension problems. (Tips for Teaching). Preventing School Failure, 47, 45-48.

16) Peregoy, S., \& Boyle, O. (2008). Reading, writing, and learning in ESL: A resource book for teaching-12 English learners

\begin{abstract}
Biography
Hasan, lahir di salokalama sebuah kampung paling ujung timur Kabupaten Enrekang yang berbatasan langsung dengan Kabupaten Sidrap. Sejak kecil menghabiskan waktu belajar d SD Negeri 160 Salokalama dan selesai pada tahun 1993. Setelah tamat SD penulis melanjutkan pendidikan di SMP Negeri Otting dan setamat SMP penulis hijrah ke kota Parepare melanjutkan pendidikan di SMK Negeri 1 Parepare dan tamat pada tahun 1999. Setelah itu menempuh perkuliahan Program Diploma di AIK AKBA Makasar (sekarang jdi STMIK AKBA Makassar) sampai pada tahun 2001. Setelah selesai program diploma penulis pernah bekerja di pulau kalimantan dan kembali melanjutkan pendidikan S1 di STKIP Muhammadiyah Sidrap selesai tahun 2014 dan melanjutkan pendidikan S2 di Universitas Muhammadiyah Parepare dan mengajar di STKIP Muhammadiyah Enrekang hingga hari ini. Penulis juga melanjutkan pendidikan S3 di Universitas Hasanuddin jurusan Linguistik.
\end{abstract}

